\title{
Extruded Full Fat Soybean in Diets for Male Turkey
}

Alsaftli ZA ${ }^{1^{*}}$, AL-Saadi MA ${ }^{1}$ and Subuh AM $^{2}$

${ }^{1}$ Department of Animal Production, Damascus University, Syria, Syrian Arab Republic

${ }^{2}$ Animal Production Department, Faculty of Veterinary Medicine, University of Al Baath, Syria, Syrian Arab Republic

*Corresponding author: Alsaftli ZA, Department of Animal Production, Damascus University, Syria, Syrian Arab Republic, Tel: 963994477258; E-mail: zelalsaftli@gmail.com

Rec date: Jan 05, 2016; Acc date: Mar 02, 2016; Pub date: Mar 04, 2016

Copyright: $\odot 2016$ Alsaftli ZA, et al. This is an open-access article distributed under the terms of the Creative Commons Attribution License, which permits unrestricted use, distribution, and reproduction in any medium, provided the original author and source are credited.

\section{Abstract}

The aim of this research was to study the effect of different levels of the extruded full-fat soybean (EFFSB) on growth performance and serum lipids of male turkeys. A trial was carried out using 300 one day male turkey B.U.T (big 6) during 3 feeding periods (starter, grower and finisher, 18 weeks). Poults were selected and divided into four experimental groups with three replicates containing 25 poults each, in a completely randomized design, and were fed experimental diets for 18 weeks. Treatments consisted on: T1 (control, SBM), T2 (10\% EFFSB), T3 (15\% EFFSB) and T4 (20\% EFFSB).

There were negligible changes in mortality. The results showed that the level of feed intake was decreased, while feed efficiency and body weight gain was improved in male turkey fed with different levels of the EFFSB. As a result, the best growth performance was determined for male turkeys fed diets containing $15 \%$ and $20 \%$ of EFFSB, which was exceeded significantly $(p<0.05)$.

The experiment confirmed that addition of extruded full-fat soybean in male turkey diets had influenced on serum lipids, so that cholesterol and triglyceride were reduced significantly $(p<0.05)$ on serum lipids of male turkey.

Keywords: Extruded; Male turkeys; Performance; Soybean; Serum lipids

\section{Introduction}

Growth depression effects due to anti-nutritional factors (ANF's) present in soybeans have been well documented for more than half a century $[1,2]$. There are few recent works on the influence of the level of use and processing of beans on productivity in turkeys. However, when preparing formulations in practice, the percentages of use have increased recently, frequently discovering diets with inclusion levels of up to $25 \%$. There are two reasons for this; on the one hand the excess linoleic acid is more harmful to the quality and the appearance of the turkey carcass than in the broiler carcass due to its lower fat content [3]. On the other hand diets for turkeys are very concentrated in protein (for newly-born) and in energy (fattening stages) and as a result, in both cases the composition and concentration of these two nutrients in the bean have high values.

In fact, in current Spanish conditions more than $70 \%$ of the protein in the starter diets comes from soya. Other additional advantages of the bean in the European Union-15 are its nature as a plant and its high-unsaturated fat content. observed those turkeys between 2 and 3 weeks old digested fats $15 \%$ more efficiently than chicks of a similar age [4], which corresponds with the results of Mossab for soybean oil [5].

Turkeys, as with chickens, are sensitive to the presence of trypsin inhibitors, with pancreatic hypersecretion and hypertrophy. Mian et al. [6] have discovered that the maximum level of trypsin inhibitors tolerated by this species was $2.5 \mathrm{mg} / \mathrm{g}$ of diet at three weeks and $3 \mathrm{mg} / \mathrm{g}$ of diet for animals above that age. Given that a feed for turkeys may contain up to $50 \%$ beans and soybean meal, the use of products that have been deficiently processed is not suitable for newly- born animals.

Moran et al. [7] compare soybean meal and raw or extruded whole soybean as a source of protein in turkeys of between 8 and 23 weeks of age. The diets based on extruded beans produced equivalent results to those obtained with the control diet. As was expected, the animals that received raw beans displayed an important reduction in productivity. Turner et al. [8] obtained similar results in turkeys between 10 and 23 weeks old with diets based on soybean meal or $23 \%$ of two different types of whole roasted soybean. Paradis et al. [9] Obtained similar levels of production in turkeys from eight weeks old until sacrifice when the soybean meal was totally or partially replaced by extruded beans.

This research aims to study the possibility of replacing soybean meal with different ratio of extruded full-fat soybean in male turkey diet, and determine the optimum ratios for replacement.

\section{Materials and Methods}

Processing of soybean: Whole soybean was gotten locally, the beans were brought to Oils factory in Damascus, for processing. Technological of soybean extruding was included: Soybean $\rightarrow$ cleaning $\rightarrow$ Grinding $\rightarrow$ Softening $\rightarrow$ Flaking $\rightarrow$ Then $\quad$ extruded without steam. Extrusion of finely ground beans has performed in laboratory scale single screw extruder (Extruder model E-250, China).

The extrusion processing was performed using a single screw extruder (Extruder model E-250, China) which was powered by a 37 $\mathrm{KW}$ motor with an operating range of screw speeds from 0 to $250 \mathrm{rpm}$, with length/diameter ratio of 25 , screw speed up to $250 \mathrm{rpm}$ and outer screw diameter of $25 \mathrm{~mm}$. feed rate $250 \mathrm{~kg} / \mathrm{hour}, 140 \mathrm{~g} / \mathrm{kg}$ feed 
Page 2 of 6

moisture content in the extruder barrel and the extrusion temperature to 140 co (die temperature), were employed.

Extruded full- fat soybean beans has cooled at room temperature, after drying; the product has placed in bags and returned to the University of Damascus for use in the feeding trials.

A sample of the product was analyzed by animal laboratory and found to contain $38.90 \%$ crude protein, $18.5 \%$ crude fat (Table 1), 0.09 urease rise, and $77 \%$ protein solubility in $0.2 \% \mathrm{KOH}$, urease level and protein solubility indicate that the FFSB was processed sufficiently to denature the trypsin inhibitor without overcooking [10,11]. A laboratory specializing in protein nutrition conducted protein analysis of the product, and the metabolizable energy content was estimated from equations published by NRC [12].

\begin{tabular}{|l|l|l|l|}
\hline Ingredient & Starter & Grower & Finisher \\
\hline Corn & 511.7 & 598.6 & 726.2 \\
\hline Soybean meal (44\%) & 383.8 & 318.2 & 245.2 \\
\hline Fish meal (61\%) & 79.4 & 61.9 & - \\
\hline Dicalcium phosphate & 2.0 & - & 2.0 \\
\hline Limestone & 15.0 & 12.0 & 15.5 \\
\hline Lysine & - & 1.8 & 1.7 \\
\hline DL- Methionin & 0.6 & - & 0.4 \\
\hline Vitamin premix1 & 2.5 & 2.5 & 2.5 \\
\hline Trace mineral2 & 2.5 & 2.5 & 2.5 \\
\hline Salt & 2.5 & 2.5 & 4.0 \\
\hline Calculated analysis & & & \\
\hline Crude protein (\%) & 25.98 & 22.77 & 16.88 \\
\hline Metabolizable energy (kcal/kg) & 2806 & 2915 & 3038 \\
\hline C/P ratio (kcal kg/\%protein) & 108 & 128 & 180 \\
\hline
\end{tabular}

Table 1: Composition ( $\mathrm{g} / \mathrm{kg}$ air dry basis) of the basal diet. 1Provided the following $/ \mathrm{kg}$ feed irrespective of the chemical form: vitamin A palmitate $4400 \mathrm{IU}$; cholecalciferol, $900 \mathrm{ICU}$; DL-tocopherol acetate, 22 IU; menadione, $1.1 \mathrm{mg}$; thiamine mononitrate, $2.75 \mathrm{mg}$; riboflavin, 5.5 $\mathrm{mg}$; calcium pantothenate, $154 \mathrm{mg}$; niacin, $70 \mathrm{mg}$; pyridoxine $\mathrm{HCl}, 4.5$ mg; biotin, $0.33 \mathrm{mg}$; choline chloride, $2200 \mathrm{mg}$; Folacin, $1 \mathrm{mg}$; vitamin B, $19.8 \mu$ g 12. 2 Supplied in $\mathrm{mg} / \mathrm{kg}$ feed: $\mathrm{Cu}$ (as copper sulfate) 8; I (as potassium iodide) 0.4; Fe (as Ferric citrate) 110; Mn (manganous sulfate) 77; Se (as sodium selenite) 0.2; and Zn (as zinc carbonate) 60.

Diets were isocaloric and isonitrogenous with a different content of extruded full-fat soybean (EFFSB). Each diet was formulated for (0 to $4 \mathrm{w}$ ) starter, ( 5 to $12 \mathrm{w}$ ) grower and (13 to $18 \mathrm{w}$ ) finisher. The basal diet had no extruded full fat soybean (control) (T1), while those for three treatments contained within 10 (T2), 15 (T3), and 20\% (T4) of extruded full fat soybean, respectively (Table 2). Soybeans were processed under temperature $140^{\circ} \mathrm{C}$ during 15 second. Diets met or exceeded the amino acid requirements suggested by the NRC [12] adjusted to the dietary energy content. Complete vitamin and trace mineral mixes obtained from a commercial poultry integrator were used. Diets were pelleted by using a pellet mill (Richard Size Limited
Engineers, Orbit 15, Kingston-upon-Hull, UK) capable of manufacturing $180 \mathrm{~kg}$ of feed/h. Diets fed from 0 to $4 \mathrm{w}$ were fed as mash.

\begin{tabular}{|l|l|l|}
\hline Age /day & The vaccine Name & Method of Vaccination \\
\hline 1 & Swallen Head Disease (SHD) & Water \\
\hline 7 & Newcastle & Water \\
\hline 15 & Turkey Rhino Tracheititis (TRT) & Injection chest \\
\hline 22 & oil emulsion vaccine & Injection chest \\
\hline 60 & smallpox vaccine & Scratching of Wing \\
\hline Newcastle vaccine will be returned on every 25 day until the end of fattening
\end{tabular}

Table 2: Vaccines were used in immunization of birds.

All diets were manufactured and stored for two weeks prior to the start of the trial and then, prior to feeding.

\section{Birds and housing}

Three hundred day-old male turkeys of a commercial turkey strain (B.U.T. big 6) were purchased from a commercial hatchery. The birds were randomly assigned to 4 dietary treatments (twenty five birds per pen and three replicate pens per treatment $(0.36 \mathrm{~m} 2$ per bird $)$ with used wood shavings over concrete floors. Each pen was contained two trough feeder and one water trough. Birds were brooded using whole house brooding, Indoor temperature was $32^{\circ} \mathrm{C}$ at the beginning of the experiment and step by step reduced $2^{\circ} \mathrm{C}$ every week to reach a constant temperature of $22 \pm 2^{\circ} \mathrm{C}$. The lighting was a continuous 24 hour in the first three days, and then were reduced to 22-hour lighting and so until the second week of life, and after the second week until the week (12) was used intermittent lighting as follows program: (16L:2D : 3L:3D). Feed was offered ad libitum and water was freely available throughout the trial. Vaccines were used in immunization of birds (Table 3).

\begin{tabular}{|l|l|l|l|l|}
\hline Treatment & \multicolumn{4}{l}{ Mortality rate (\%) } \\
\hline & Starter & Grower & Finisher & Total \\
\hline T1 & 4 NS & 2.78 NS & 2.84 NS & 9.33 NS \\
\hline T2 & 2.67 & 2.72 & 2.78 & 8 \\
\hline T3 & 2.67 & 5.44 & 1.45 & 9.33 \\
\hline T4 & 2.67 & 2.72 & 1.39 & 6.67 \\
\hline
\end{tabular}

Table 3: Effect of different levels of extruded soybean on mortality rate of male turkey. NS: Not Significant.

\section{Growth performance}

Birds and feed were weighed in the $4^{\text {th }}, 12^{\text {th }}$ and $18^{\text {th }}$ weeks and individually to determine Body weight gain (BWG), feed intake (FI) and Feed Conversion Ratio (FCR).

\section{Serum lipids}

At the end of the period three turkey broilers were selected from each replicate and blood samples were collected from wing veins, 
Page 3 of 6

approximately $5 \mathrm{ml}$ of blood were taken from each bird for the analysis.

Serum triacylglycerol, total-and high density lipoprotein (HDL)cholesterol of the

chickens were measured by appropriate methods [8,10,13-21]. Serum low density lipoprotein (LDL) cholesterol was calculated using Friedewald equation [2], LDL-chol=total cholesterol-HDL-choltriglyceride/5.

\section{Statistical analysis}

Data from study were subjected to a statistical analysis by one-way analysis of variance test (ANOVA) using the General Linear Model procedure of Anderson-Haferman et al. [22]. Differences were considered to be significant at $\mathrm{P}<0.05$ and significant differences between means were separated by the Fisher's Least Significant Difference test.

\section{Results and Discussion}

Results of the study relating to effects of experimental diets on performance in turkey poults were in Tables 4, 5, 6 and 7.

\begin{tabular}{|c|c|c|c|c|}
\hline \multirow[t]{2}{*}{ Treatment } & \multicolumn{4}{|c|}{ BWG (kg/bird) } \\
\hline & Starter & Grower & Finisher & Total \\
\hline $\mathrm{T} 1$ & $1,242^{b}$ & $8,400^{b}$ & $7,506^{b}$ & $17,148^{b}$ \\
\hline $\mathrm{T} 2$ & $1,282^{a}$ & $8,451^{a b}$ & $7,594^{\mathrm{a}}$ & $17,327^{a b}$ \\
\hline T3 & $1,269^{a b}$ & $8,505^{a}$ & $7,619^{a}$ & $17,393^{a}$ \\
\hline $\mathrm{T} 4$ & $1,251^{\mathrm{ab}}$ & $8,489^{a}$ & $7,658^{a}$ & $17,399^{a}$ \\
\hline LSD1 & 0.034 & 0.087 & 0.076 & 0.195 \\
\hline
\end{tabular}

Table 4: Effect of different levels of extruded full fat soybean on Body weight gain of male turkey. ${ }^{\mathrm{a}, \mathrm{b}}$ Values in the same Column not sharing a common superscript differ significantly $(\mathrm{P}<0.05)$. ${ }^{1}$ Least significant differences of means (5\% level). NS: Not Significant.

\begin{tabular}{|c|c|c|c|c|}
\hline \multirow[t]{2}{*}{ Treatment } & \multicolumn{4}{|c|}{ Fl (kg/bird) } \\
\hline & Starter & Grower & Finisher & Total \\
\hline $\mathrm{T} 1$ & $1,600 \mathrm{NS}$ & $15,343 \mathrm{NS}$ & 20,957 NS & $37,900 \mathrm{NS}$ \\
\hline $\mathrm{T} 2$ & 1,597 & 15.337 & 20.904 & 37,838 \\
\hline T3 & 1,592 & 15,331 & 20,899 & 37,821 \\
\hline $\mathrm{T} 4$ & 1,574 & 15,323 & 20,840 & 37,736 \\
\hline LSD1 & - & - & - & - \\
\hline
\end{tabular}

Table 5: Effect of different levels of extruded soybean on feed intake of male turkey. ${ }^{\mathrm{a}, \mathrm{b}}$ Values in the same Column not sharing a common superscript differ significantly $(\mathrm{P}<0.05) .{ }^{1}$ Least significant differences of means (5\% level). NS: Not Significant.

\begin{tabular}{|l|l|l|l|l|}
\hline Treatment & \multicolumn{4}{l|}{ FCR (Feed: Gain) } \\
\hline & Starter & Grower & Finisher & Total \\
\hline
\end{tabular}

\begin{tabular}{|l|l|l|l|l|}
\hline T1 & $1.289 \mathrm{NS}$ & $1.828 \mathrm{NS}$ & $2.792^{\mathrm{a}}$ & $2.210^{\mathrm{a}}$ \\
\hline T2 & 1.245 & 1.815 & $2.753^{\mathrm{ab}}$ & $2.184^{\mathrm{ab}}$ \\
\hline T3 & 1.255 & 1.803 & $2.743^{\mathrm{b}}$ & $2.175^{\mathrm{b}}$ \\
\hline T4 & 1.258 & 1.805 & $2.721^{\mathrm{b}}$ & $2.169^{\mathrm{b}}$ \\
\hline LSD1 & - & - & 0.040 & 0.033 \\
\hline
\end{tabular}

Table 6: Effect of different levels of extruded full fat soybean on feed conversion ratio of male turkey. ${ }^{\mathrm{a}, \mathrm{b}}$ Values in the same Column not sharing a common superscript differ significantly $(\mathrm{P}<0.05) .{ }^{1}$ Least significant differences of means ( $5 \%$ level). NS: Not Significant.

\begin{tabular}{|l|l|l|l|l|}
\hline Treatment & \multicolumn{4}{l}{ Parameters $\left(\mathbf{m g}^{-d_{L}}{ }^{-1}\right)$} \\
\hline & Cholesterol & Triglyceride & LDL & HDL \\
\hline T1 & $146.23^{\mathrm{a}}$ & $48.1^{\mathrm{a}}$ & $103.18 \mathrm{NS}$ & $33.43 \mathrm{NS}$ \\
\hline T2 & $145.43^{\mathrm{ab}}$ & $45.67^{\mathrm{ab}}$ & 101.53 & 34.77 \\
\hline T3 & $144.03^{\mathrm{b}}$ & $45.8^{\mathrm{ab}}$ & 101.54 & 33.33 \\
\hline T4 & $144.13^{\mathrm{b}}$ & $43.33^{\mathrm{b}}$ & 101.8 & 33.67 \\
\hline LSD1 & 1.4 & 2.55 & - & - \\
\hline
\end{tabular}

Table 7: Effect of different levels of extruded full fat soybean on serum lipid of male turkey. ${ }^{\mathrm{a} b}$ Values in the same Column not sharing a common superscript differ significantly $(\mathrm{P}<0.05)$. ${ }^{1}$ Least significant differences of means ( $5 \%$ level). NS: Not Significant.

\section{Mortality}

The results in Table 4 showed that mortality rates of birds during the experimental period did not influence by dietary supplementation of EFFSB. Similar results were obtained by Subuh [19]. This implies that EFFSB supplementation had no toxicity with the birds.

\section{Body weight gain}

The Body weight gain of poults during periods in the experimental groups fed different levels of extruded full fat soybean were increased than control group in Table 5. Lower BWG of turkeys $(p<0.05)$ was found for the starter period in the control treatment $(1,242 \mathrm{Kg})$ compared to the average BWG of T2 $(1,282 \mathrm{Kg})$. Differences $(\mathrm{p}<0.05)$ were also found on BWG for the grower period between the control treatment $(8,400 \mathrm{Kg})$ and the treatments $\mathrm{T} 3$ and $\mathrm{T} 4(8,505$ and 8,489 $\mathrm{Kg}$, respectively). The BWG of turkeys for the finisher and total periods was lower $(p<0.05)$ in the control treatment $(17,148 \mathrm{Kg})$ than in the treatments T3 and T4 (17,393, and 19,399 Kg, respectively), without any significant differences among these EFFSB treatments. Heat treatment, in addition to destroying thermolabile antinutritional factors, also opens up the tertiary structure of proteins and improves their digestibility Anderson-Haferman et al. [22]. However, what must be considered is the fact that BWG of turkeys due to fed with the extruded full-fat soybean from $15 \%$ to $20 \%$ at the finisher period was increased than control diet $(\mathrm{p}<0.05)$. This significantly increase probably due to absence of fishmeal in this period. Feeding high-fat diets to young poults (up to 14 days of age) is an important topic that deserves some discussion. Current industry wisdom among nutritionists is to minimize supplemental fat levels in diets for poults 
between 14 and 28 days of age. Thereafter, it is generally accepted that fat utilization increases with age. Several researchers have supported this concept from a fat digestibility perspective [14,17,23]. The improvement in fat utilization with age is largely a function of increased bile production and intestinal lipase activity as the poult matures.

The positive impact clearly has been observed to add extruded soybean with the progress of the birds at the age during the last phase of life with the increasing need for energy and the lack of fish meal in the ration, which confirms that the extruded soybean is not only a good source of protein, but also a good source energy. The results of the present study was in conformity with the results of previous studies $[24,25]$ from viewpoints body weight gain and increased level of EFFSB. Whereas, these findings were not in conformity with results of some other studies [26] from based on the fact that of lack of effectiveness of extrusion on broiler body weight gain.

\section{Feed intake}

The results showed that there were no significant differences ( $p>0.05)$ on FI of turkeys for the starter, grower, finisher and total periods between the control treatment and the others (Table 6). Nevertheless, total period FI was higher $(\mathrm{p}>0.05)$ in the control treatment $(37,900 \mathrm{Kg})$ than in the $\mathrm{T} 2, \mathrm{~T} 3$ and $\mathrm{T} 4(37,838,37,821$, and $37,736 \mathrm{Kg}$, respectively). The findings of the present study is in conformity with the findings of the previous research works [26,27], but at the same time they were not in conformity with the findings of the researchers who witnessed increased intake of EFFSB [16]. This might be due to an underestimation of the energy content of the beans used, and was probably because the energy value available to the bird because of rolling and extrusion, coupled with pelleting of the diets, was underestimated. Wiseman [28] also showed that the ME value of diets containing extruded whole soybean were greatly enhanced by pelleting the diets.

\section{Feed conversion ratio (FCR)}

The results relating to effects of experimental diets on feed conversion ratio (FCR) of turkeys in starter, grower showed that there were no significant differences $(p>0.05)$ between the control treatment and the others Table 7.

Differences were found $(\mathrm{p}<0.05)$ on FCR for the finisher and total periods between the control (2.792 and 2.210$)$ and $\mathrm{T} 3(2.743,2.175)$, T4 $(2.721,2.169)$ respectively. However, no differences were found between the three EFFSB treatments on FCR of turkeys for the starter, grower, finisher and total periods. This finding was in line with the results of the research works done on broilers fed on EFFSB, which found out that the FCR decreased significantly [25]. Furthermore, FCR in experimental groups, which received regular level of the full fat soybean seed, it was significantly compared to the control group. Nevertheless, it was not significant among the groups fed with different levels of the EFFSB. The reason for such discrepancy could be due to the apparent increase in indigestibility of protein, starch, and nonstarch polysaccharides in ileum. Processing improves the availability of the lipid and protein fractions of the bean and increases its nutritional value. Furthermore, the inclusion of fats in the feed may improve the digestibility of other fractions in the diet such as protein and carbohydrates $[29,30]$.
These results were in line with the results obtained in previous research works, which reflect positive effect of extruded feed on increased FCR and as a result, performance of poultry $[16,26]$.

Results showed, it can also be claimed that the $15 \%$ and 20\% EFFSB is suitable due to higher weight gain and decreased FCR. Therefore, it is suggested that future research studies with over 20\% EFFSB diet are undertaken to see if better result can be achieved. Moreover, Sirtori et al. [17] indicated that whole extruded will enhance nutrient release and denature the trypsin inhibitor, was a highly effective feed ingredient for broiler diets.

\section{Serum lipids}

Cholesterol is the precursor of all steroid hormones and bile salts. Cholesterol levels may vary depending on the climatic conditions of the environment, nutrition, fitness broilers and sexual activity [31]. Data in Table 7 showed that utilization of the extruded full-fat soybean had significant effect in serum lipids of the turkeys. The serum cholesterol was a function of sinusoidal curve of the extruded soybean in a way that with increased level of soybean, the cholesterol serum significantly decreased with birds fed the extruded full-fat soybean from $15 \%\left(144.03 \mathrm{mg} \cdot \mathrm{dL}^{-1}\right)$ to $20 \%\left(144.13 \mathrm{mg} \cdot \mathrm{dL}^{-1}\right)$ compared to the level cholesterol serum of control $\left(146.23 \mathrm{mg} \cdot \mathrm{dL}^{-1}\right)(\mathrm{p}<0.05)$. Plantderived protein especially extruded full-fat soybean has been shown to decrease cholesterol.

The effect of extruded soybean on triglyceride was significant as the level of extruded soybean increased resulting in lower concentration triglyceride significantly with birds fed the extruded full-fat soybean $20 \%\left(43.33 \mathrm{mg} \cdot \mathrm{dL}^{-1}\right)$ compared to the level triglyceride serum of control $\quad\left(48.1 \mathrm{mg} \cdot \mathrm{dL}^{-1}\right) \quad(\mathrm{p}<0.05)$. But LDL levels decreased insignificantly with birds fed the extruded full-fat soybean $(\mathrm{p}>0.05)$. Anderson [32] reported that serum lipoprotein concentrations could be changed by dietary fat in broilers. Ham et al. [33] reported that EFFBS was effective in lowering the levels of serum triglycerides and cholesterol in humans and animals. However, the mechanism of FFSB on blood cholesterol is unknown, although several theories have been proposed. One hypothesis suggests that the amino acid composition of FFSB protein causes some changes in cholesterol metabolism. In other studies, some authors proposed that non-protein components (such as fiber and isoflavones) associated with FFSB protein affect cholesterol metabolism either directly or indirectly [34].

Soybean contains isoflavonids (genistein and daidzein) that have estrogenic effects [35]. Yousef [36] showed a positive effect of isoflavonids on biochemical parameters of blood in male rabbits. Isoflavonids led to the lowering of cholesterol and triglycerides. Oligosaccharides may have significant impact on reducing levels of cholesterol and triglycerides in rats fed with high fat content [37]. And thus lipoproteins low density may be reduced due to the presence of soybean oil in the diet, which contains a high proportion of unsaturated fatty acid, and the liver converts unsaturated fatty acid preferentially to bodies of ketone instead of lipoproteins LDL or triglycerides, and are transferred acids to the tissues of the oxidation without the impact of lipoproteins stays low density [38]. The most popular theory suggests that FFSB protein reduces cholesterol metabolism in the liver by increasing the removal of LDL 'bad' cholesterol [17].

HDL level were not influenced by inclusion rate of EFFSB ( $p>0.05)$. Serum HDL carries about $75 \%$ of total cholesterol in broiler [39], it is 
Page 5 of 6

more likely that this lipoprotein may be more influence by the type of dietary fat.

\section{Conclusion}

In conclusion, the results of this experiment point to that use of extruded full-fat soybean in male turkey diets did not has any negative effect on performance of male Turkeys during the whole period. Inclusion dietary different levels of from 10 to $20 \%$ on diet is decreased FI and BWG increased of turkey. Therefore, utilization of the EFFSB at the 20\% level led to decrease FCR of turkeys. The experiment confirmed that add extruded full-fat soybean in male turkey diets has influenced on serum lipids, so that it reduced cholesterol, triglyceride and LDL on serum lipid of male turkey. In the end, we recommend to used up to $20 \%$ extruded soybeans in male turkeys diet.

\section{Acknowledgements}

This is a part of the $\mathrm{PhD}$ dissertation work of the first author. We would like to acknowledge the University of Damascus for financial support of this research. In addition, author wishes to thank the Agricultural organization of Damascus province for providing the data used in this study.

\section{References}

1. Chernick SS, Lepkovsky S, Chikoff IL (1948) A dietary factor regulating the enzyme content of the pancreas: Changes induced in size and proteolytic activity of the chick pancreas by the ingestion of raw soybean meal. Am J Physiol 155: 33-41.

2. Friedewald WT, Levy RI, Fredrickson DS (1972) Estimation of the concentration of low-density lipoprotein cholesterol in plasma, without use of the preparative ultracentrifuge. Clin Chem 18: 499-502.

3. Lessire $M$ (2001) Matières grasses alimentaires et composition lipidique des volailles. INRA Producton Animal 14: 365-370.

4. Lall SP, Slinger SJ (1973) The metabolizable energy content of rapeseed oil foods and the effect of blending with other fats. Poultry Science. 52: 143-151.

5. Mossab A, Hallouis JM, Lessire M (2000) Utilization of soybean oil and tallow in young turkeys compared with young chickens. Poult Sci 79: 1326-1331.

6. Mian MA, Garlich JD (1995) Tolerance of turkeys to diets high in trypsin inhibitor activity from undertoasted soybean meals. Poult Sci 74: 1126-1133.

7. Moran ET, Somers J, Larmond E (1973) Fullfat soybeans for growing and finishing turkeys. Live performance and carcass quality. Poultry Science 52: $1936-1973$.

8. Turner CA, Kienholz EW, Harper JM, Raghavan V (1973) Roasted soybeans in growing and finishing diets for turkeys. Feedstuffs Enero pp: 30-31.

9. Paradis PL, Harper JA, Nakaue HS, Arscott GH (1977) The feeding value of Pacific North West grown soybeans for market turkeys. Oregon State University Special Report Nth 497. Corvallis, Oregon, United States.

10. Waldroup PW, Ransey BE, Hellwig HM, Smith NK (1985) Optimum processing for soybean meal used in broiler diets. Poultry Sci 64: 2314-2320.

11. Dale NM, Arabra M (1987) Protein solubility as an indicator of optimum processing of soya bean meal. Proceedings of the Georgia Nutrition Conference, University of Georgia, Athens, USA. Poultry Sci 69: 1749-1752.

12. NRC (1994) National Research Council. Nutrient requirements of poultry. 9th edn. National Academy Press. Washington DC, USA.

13. Roeschlau P, Bernt E, Gruber W (1974) Enzymatic determination of total cholesterol in serum. Z Klin Biochem 12: 226.
14. Salmon RE (1977) Effects of age on the absorption of fat by turkeys fed mixtures of beef fat and rapeseed oil. Can J Anim Sci 57: 427-431.

15. SAS Institute (1997) SAS/STAT ${ }^{\circledast}$ User's Guide: Statistics. Version 6.12. SAS Institute Inc., Cary, NC, USA.

16. Sell JL, Krogdahl A, Hanyu N (1986) Influence of age on utilization of supplemental fats by young turkeys. Poult Sci 65: 546-554.

17. Sirtori CR, Lovati MR, Manzoni C, Gianazza E, Bondioli A, et al. (1995) Reduction of serum cholesterol by soy proteins. Nutr Metab Cardiovasc Dis 8: 334-340.

18. Smulikowska S, Czerwinski J, Mieczkowska A (2006) Nutritional value of rapeseed expeller cake for broilers: effect of dry extrusion. Journal Animal Feed Science 15: 445-453.

19. Subuh AMH, Motl MA, Fritts CA, Waldroup PW (2002) Use of various rations of extruded fullfat soybean meal and dehulled solvent extacted soybean meal in broiler diets. International J of Poultry Science 1: 09-12.

20. Summers JD (1984) The extracaloric value of fats in poultry diets. In: Fats in Animal Nutrition. Wiseman J (Ed) Butterworths, London, United Kingdom pp: 265-276.

21. Warnick GR, Benderson J, Albers JJ (1982) Dextran sulfate- $\mathrm{Mg}^{2+}$ precipitation procedure for quantitation of high-density-lipoprotein cholesterol. Clin Chem 28: 1379-1388.

22. Anderson-Haferman JC, ZhangY, Parsons CM, Hymowitz T (1992) Effect of heating on the nutritional quality of Kunitz-trypsin-inhibitor-free and conventional soybeans for chicks. Poultry Sci 71: 1700-1709.

23. Whitehead CC, Fisher C (1975) The utilisation of various fats by turkeys of different ages. Br Poult Sci 16: 481-485.

24. Jonez ET, Anderson KE, Ferket PR (1995) Effect of extrusion on feed charecteristics and broiler chiken performance. J Appl Poult Res 4: 300-309.

25. Leeson S, Atteh JO (1999) Response of broiler chicks to dietary full-fat soybeans extruded at different temperatures prior to or after grinding. Anim Feed Sci Technol 57: 239-245.

26. Marsman GJP, Gruppen H, Van Der Poel AFB, Kwakkel RP (1997) The effect of thermal processing and enzyme treatments of soybean meal on growth performance, ileal nutrient digestibilities, and chyme characteristics in broiler chicks. Poult Sci 76: 864-872.

27. Nalle CL, Ravindran G, Ravindran V (2011) Extrusion of Peas (Pisum sativum L.): Effects on the Apparent Metabolisable Energy and Ileal Nutrient Digestibility of Broilers. American J Anim Vet Sci 6: 25-30.

28. Wiseman J (1984) Developments in utilization of full fat soybean meal for non-ruminants. Feed International p: 14.

29. Aranibar JM (2002) Influencia del ayuno postnacimiento y de las características del pienso de iniciación sobre la fisiología digestiva y la productividad del pollo broiler. Doctoral thesis. Universidad Politécnica de Madrid.

30. Itoh N, Makita T, Koiwa M (1998) Characteristics of blood chemical parameters in male and female quails. J Vet Med Sci 60: 1035-1037.

31. Hermier D, Dillon JC (1992) Characterization of dietary-induced hypercholesterolemia in the chicken. Biochim Biophys Acta 1124: 178-184.

32. Anderson JW, Johnstone BM, Cook-Newell ME (1995) Meta-analysis of the effects of soy protein intake on serum lipids. N Engl J Med 333: 276-282.

33. Ham WE, Sandstedt RM, Mussehl FE (1945) The proteolytic inhibiting substance in the extract from unheated soy bean meal and its effect upon growth in chicks. J Biol Chem 161: 635-642.

34. Potter SM (1995) Overview of proposed mechanisms for the hypocholesterolemic effect of soy. J Nutr 125: 606S-611S.

35. Messina MJ (1999) Legumes and soybeans: overview of their nutritional profiles and health effects. Am J Clin Nutr 70: 439S-450S.

36. Yousef MI, el-Demerdash FM, Kamel KI, Al-Salhen KS (2003) Changes in some hematological and biochemical indices of rabbits induced by isoflavones and cypermethrin. Toxicology 189: 223-234. 
Citation: Alsaftli ZA, Saadi MAA, Subuh AM (2016) Extruded Full Fat Soybean in Diets for Male Turkey. J Veterinar Sci Technol 7: 311. doi: 10.4172/2157-7579.1000311

Page 6 of 6

37. Chen H, Li-Jun L, Jian-Jun Z, Bo X, Rui L (2010) Effect of soybean oligosaccharides on blood lipid, glucose levels and antioxidant enzymes activity in high fat rats. Food Chemistry 119: 1633-1636.

38. Nitsan Z, Dvorin A, Zoref Z, Mokady S (1997) Effect of added soyabean oil and dietary energy on metabolisable and net energy of broiler diets. $\mathrm{Br}$ Poult Sci 38: 101-106.
39. Peebles ED, Cheaney JD, Brake JD, Boyle CR, Latour MA (1997) Effects of added dietary lard on body weight and serum glucose and low density lipoprotein cholesterol in random bred broiler chickens. Poult Sci 76: $29-36$ 